\title{
Zebrafish $A B C C 5$ gene expression in relation to metallic contamination and presence of Tubifex worms
}

\author{
Dalia M. Sabri ${ }^{1,4^{*}}$, Tarik Rabie ${ }^{2}$, Ashraf I. Ahmed ${ }^{3}$, Saad Zakaria ${ }^{3}$ and \\ Jean-Paul Bourdineaud ${ }^{4}$ \\ 1- Biotechnology Research Center (BRC), Suez Canal University, Ismailia 41522, \\ Egypt. \\ 2- Department of Animal Production, Faculty of Agriculture, Suez Canal University, \\ Ismailia 41522, Egypt. \\ 3- Department of Marine Science, Faculty of Science, Suez Canal University, Ismailia \\ 41522, Egypt. \\ 4- Bordeaux University, CNRS, UMR EPOC 5805, Arcachon Marine Station, \\ Arcachon 33120, France. \\ * Corresponding author's e-mail: dotsab@yahoo.com.
}

\section{ABSTRACT}

The impact of contaminated sediment with copper and cadmium on the expression of $A B C C 5$ gene expression in Zebrafish Danio rerio was studied after seven days of exposure. Also the effect of Tubifex worms as bioturbator organism on the gene expression was investigated. Expression of $A B C C 5$ gene was estimated in Zebrafish brain, gills, muscles and digestive tract tissues in four different experimental conditions. The highest expression for ABCC5 gene was found in brain samples of all tested groups, while the gene expression in gills didn't show any significant change in all groups. Presence of $\mathrm{Cu}$ and $\mathrm{Cd}$ had led to a significant increase in the expression of $A B C C 5$ gene in brain and digestive tract samples. Surprisingly, in presence of Tubifex worms, expression of the same gene was higher in zebrafish tissues than expression in normal condition in absence of Tubifex worms. The only exception was in gills tissues, where a lower expression was detected.

Keywords: ABCC5 gene, Danio rerio, heavy metals, Lake Manzala, Tubifex tubifex.

\section{INTRODUCTION}

The drastic increase in heavy metals contamination in Egyptian lakes is a serious and continuous problem. Particularly, Lake Manzala has been identified by the Egyptian international environmental action plan as one of the most heavily polluted water bodies in Egypt (Abdel-Gawad \& El-Sayed, 1998). Its sediment has exceeded the maximum permissible limits for worldwide soil reference (MPL) with concentrations of 33386.64, 432.16, 315.36, 419.6, 48.8 and $134.64 \mathrm{mg} / \mathrm{kg}$ for Fe, Zn, $\mathrm{Cu}, \mathrm{Mn}, \mathrm{Cd}$ and $\mathrm{Pb}$ respectively (Saeed \& Shaker, 2008). High level of heavy metals lead to different ecological consequences (Jha, 2008, Pomati et al., 2008) in species survival, population size, and biodiversity (Nehls \& Segner, 2001). Moreover, it might cause DNA damage in the exposed organisms (Rank et al., 2005; Matsumoto et al., 2006; Barbosa et al., 2009).

Among the 23 heavy metal elements, Cadmium (Cd) is a highly toxic and carcinogenic metal on the aquatic organisms even at low levels of contamination (Glanze, 1996). In addition, it has been classified as a human carcinogen (group I) (IARC, 1993). It has serious effects on mitochondrial metabolism and integrity that lead to increase in the reactive oxygen species (ROS) production causing oxidative 
stress (Bagchi et al., 2000; Chan \& Cheng, 2003), and inhibition in the DNA repair system (Bertin \& Averbeck, 2006; Giaginis et al., 2006; Joseph, 2009).

Other metals such as Copper $(\mathrm{Cu})$ is an essential micronutrient for plants, animals and some microorganism. It is required for vital biological processes (RiveraMancia et al., 2010). High level of $\mathrm{Cu}$ exposure cause several toxic effects such as endocrine disruption (Teles et al., 2005), ionoregulation disturbance, growth reduction (Ricard et al., 1998), ROS production, and cellular and DNA damage (Gabbianelli et al., 2003; Bagdonas \& Vosylienè, 2006).

Fish like other aquatic organisms use protective ROS-scavenging enzymes like superoxide dismutase (SOD), catalase (CAT), and ATP-binding cassette transporters (ABC-transporter) to combat the high levels of ROS.

ATP-binding transporter (ABC-transporter) is one of the largest protein superfamilies, exists in the cells of all the living organisms (Jones \& George, 2004; Ponte-Sucre, 2009). It consists of eight subfamilies in eukaryotes (A-H) (Dean \& Anillo, 2005), which have a great role in translocating various substrates and molecules across cellular membranes. Also they are involved in many cellular processes; nutrient uptake, maintenance of osmotic homeostasis, tumor resistance, and xenotoxins resistance (Schneider \& Hunke, 1998).

ABC transporters, subfamily $\mathrm{C}$ are identified as multidrug-resistance associated proteins (MRPs). The ABCC/MRPs have protective functions in vital body organs from toxins by preventing toxins uptake from gut to the whole body (Leslie et al., 2005). ABCC subfamily is highly expressed in brain, liver, testis, ovaries and embryos (Long et al., 2011) and has participated in heavy metals detoxification (Weaver et al., 2005).

Zebrafish, Danio rerio is widely used as a model organism in toxicological and genetic studies (Teraoka et al., 2003; Blechinger et al., 2007; Jin et al., 2008; Scholz et al.; 2008; Orieux et al. 2011; Rocco et al., 2011,), due to its small size, rapid growth, short lifecycles, and to its well characterized embryonic development. As well as to it's recently completed and published genome sequence (Broughton et al., 2001; Spitsbergen \& Kent, 2003; Hill et al., 2005; Gilbert, 2006)

Sludge worm Tubifex tubifex is used as bioindicator in ecotoxicological studies, because of its position in the aquatic food web (Gillis et al., 2004; Van der Geest \& Leon Paumen, 2008). Tubifex is a macrobenthos organism lives in the sediment of freshwater lakes and rivers (Zendt \& Bergersen, 2000). It has an important role in the physical and chemical activities in the sediment-water interface (Fisher, 1982), metals transfer and bioavailabilty between sediment and water column (Ciutat \& Boudou, 2003; Anschutz et al., 2012).

Few genotoxicological studies have investigated the effect of heavy metals contamination on the expression of Zebrafish ABCC5 gene, while no recorded information about the effect of metallic contamination in presence of Tubifex worms on Zebrafish $A B C C 5$ expression.

Thus, the aim of this study is to investigate the impact of contaminated sediment (with environmentally relevant doses of $\mathrm{Cu}$ and $\mathrm{Cd}$ found in Lake Manzala) on Zebrafish ABCC5 expression in presence and absence of Tubifex worms.

\section{MATERIALS AND METHODS}

\section{Animals maintenance}

Adult males Zebrafish (Danio rerio) were purchased from a local pet farm in Bordeaux-France, and kept in polyethylene tank filled with chlorine-free water with 
continuous aeration. They were fed twice a day with total amount of 50mg diet /fish/day for acclimation period of 30 days.

Sixty batches $₹ 200$ worms/batch) of tubificidae worms, Tubifex tubifex were purchased from natural pond (SARL GREBIL père \& fils, Paris - France). Worms were released on clean sediment from Garonne River, Bordeaux-France at $20^{\circ} \mathrm{C}$ for 15 days as acclimation period.

\section{Sediment preparation and heavy metals contamination}

Uncontaminated sediment from Garonne River, Bordeaux-France was collected, sieved and homogenized with stock solution of Copper (Copper standard, $\mathrm{Cu}$-Titrisol, Merck) and Cadmium (Cadmium standard, $\mathrm{CdCl}_{2}$-Titrisol, Merck) to have a final concentration of $315 \mathrm{mg} / \mathrm{kg}$ and $84.8 \mathrm{mg} / \mathrm{kg}$ of $\mathrm{Cu}$ and Cd respectively. Sediment was left seven days at $4^{\circ} \mathrm{C}$ for full homogenization with the contaminants.

\section{Experimental design}

The experimental protocol was carried out in Arcachon marine station, Arcachon-France. Twelve glass aquaria $(12 \mathrm{X} 12 \mathrm{X} 30 \mathrm{~cm})$ were used as Experimental units (EUs). Seven $\mathrm{cm}$ of the EUs were filled with sediment (uncontaminated or contaminated), then they were covered with $14 \mathrm{~cm}$ of water column. All experimental unites were arranged in a thermostatic chamber at $21^{\circ} \mathrm{C}$ with source of aeration, and $12 \mathrm{hr}$ photoperiod of florescent light for seven days of exposure.

The EUs were divided into four different conditions, three replicates for each. Two control groups; C group (uncontaminated sediment + fish -worms), and D group (uncontaminated sediment + fish+ worms). And two contaminated groups; F group (contaminated sediment + fish -worms), and G group (contaminated sediment + fish + worms).

Zebra fish was distributed randomly, four fish per each unit, while worms were distributed as 56000 worms $/ \mathrm{m}^{2}$ in D and G conditions only.

\section{Total RNA Isolation}

After seven days of exposure, five fish samples from each condition were killed with cold shock in melting ice and dissected to collect skeletal muscles, digestive tract, gills and brain samples. All tissue samples were stored in RNA later solution (Qiagene) at $-80^{\circ} \mathrm{C}$.

Total RNAs were isolated from tissue samples using Absolutely RNA miniprep kit (Agilant), tissue samples were homogenized with lyses buffer to denaturate proteins, followed by prefiltration step to remove particles and to reduce DNA amount. In the third step, low salt buffer and DNase were added to remove the remaining DNA. Series of washes were applied to remove the DNase and protein, finally highly pure RNA was eluted in elution buffer. Then, the first strand of cDNA was synthesized using Affinity Script cDNA synthesis kit (Agilent).

\section{Real-Time PCR}

Primers for Zebrafish ABCC5 and $\beta$-Actin genes (Housekeeping gene) were designed according to their sequence in the gene bank (table1).

Table 1: Primers sequence in Gen Bank

\begin{tabular}{|c|c|l|}
\hline Gene & Accession number & \multicolumn{1}{c|}{ Sequence } \\
\hline $\boldsymbol{\beta}$-Actin & NM_131031 & $\begin{array}{l}\text { 5'-AAGTGCGACGTGGACA-3' } \\
\text { 3'-GTTTAGGTTGGTCGTTCGTTTG-5' }\end{array}$ \\
\hline ABCC5 & XM_002665402 & $\begin{array}{l}\text { 5'-CGGCAGTGTTTTCCCCT-3' } \\
\text { 3'CCGTACG CATGAACGGT-5' }\end{array}$ \\
\hline
\end{tabular}


The PCR reactions were carried out in a total volume of $25 \mu$ contained $1 \mu \mathrm{l}$ cDNA template, $2 \mu \mathrm{l}$ primer, $12.5 \mu \mathrm{l}$ Brilliant SYBER green master mix and $9.5 \mu \mathrm{l}$ deionized water. Real-time PCR reactions were performed in real-time PCR device (STRATAGENE ). The thermal profile used for PCR amplification; one cycle for 10 min at $95^{\circ} \mathrm{C}, 40$ cycles: $30 \mathrm{~s}$ at $95^{\circ} \mathrm{C}, 30$ s at $55^{\circ} \mathrm{C}$ and 30 s at $72{ }^{\circ} \mathrm{C}$.

$\mathrm{C}_{\mathrm{t}} \mathrm{s}$ (cycles threshold) for PCR reactions were collected and relative quantification for gene expression was calculated according to the equation: $2^{\wedge}-\left(\Delta C_{t}\right)$

$\Delta \mathrm{C}_{\mathrm{t}}=\mathrm{C}_{\mathrm{t}}$ (Housekeeping gene) $-\mathrm{C}_{\mathrm{t}}$ (Target gene) (Cambier et al., 2010).

In addition, the differential gene expression was calculated as follows:

$\mathrm{D} / \mathrm{C}=$ differential gene expression for group $\mathrm{D}$ against $\mathrm{C}=2^{-\Delta \mathrm{Ct}(\mathrm{D})} / 2^{-\Delta \mathrm{Ct}}(\mathrm{C})$

$\mathrm{F} / \mathrm{C}=$ differential gene expression for group $\mathrm{F}$ against $\mathrm{C}=2^{-\Delta \mathrm{Ct}(\mathrm{F})} / 2^{-\Delta \mathrm{Ct}(\mathrm{C})}$

$\mathrm{G} / \mathrm{C}=$ differential gene expression for group $\mathrm{G}$ against $\mathrm{C}=2^{-\Delta \mathrm{Ct}(\mathrm{G})} / 2^{-\Delta \mathrm{Ct}(\mathrm{C})}$

$\mathrm{F} / \mathrm{D}=$ differential gene expression for group $\mathrm{F}$ against $\mathrm{D}=2^{-\Delta \mathrm{Ct}(\mathrm{F})} / 2^{-\Delta \mathrm{Ct}(\mathrm{D})}$

$\mathrm{G} / \mathrm{D}=$ differential gene expression for group $\mathrm{G}$ against $\mathrm{D}=2^{-\Delta \mathrm{Ct}(\mathrm{G})} / 2^{-\Delta \mathrm{Ct}(\mathrm{D})}$

$\mathrm{G} / \mathrm{F}=$ differential gene expression for group $\mathrm{G}$ against $\mathrm{F}=2^{-\Delta \mathrm{Ct}(\mathrm{G})} / 2^{-\Delta \mathrm{Ct}(\mathrm{F})}$

Statistical analysis

The differential gene expression was tested for significance using non parametric Mann-Whitney test $(\mathrm{P}<0.05)$, after applying the Shapiro-Wilk normality test (1\% risk) using SigmaStat 3.5 program.

\section{RESULTS}

\section{Relative expression of Zebrafish $A B C C 5$ gene in different organs}

Four experimental conditions C, D, F and G were studied to investigate the impact of both contaminated sediment with $\mathrm{Cu}$ and $\mathrm{Cd}$ and Tubifex worms on Zebrafish ABCB5 gene expression. For each experimental condition, the relative expression of $A B C C 5$ gene to $\beta$-actin was calculated in four organs (brain, gills, muscles, digestive tract).

Brain samples showed the highest level of $A B C C 5$ expression among the four organs in the four experimental conditions. And in overall results, the gene expression recorded the highest expression level in brain samples of the contaminated group F.

While other organs recorded different patterns in the different experimental conditions. Moreover, ABCC5 expression in digestive tract samples recorded the second position after brain samples followed by muscles then gills in experimental groups D and G, where Tubifex worms were present. While in absence of Tubifex worms in $\mathrm{C}$ and $\mathrm{F}$ groups, the $A B C C 5$ gene was highly expressed in brain samples, then gills, followed by muscles and digestive tract samples (Fig.1).

\section{The differential gene expression of Zebrafish $A B C C 5$ gene}

\section{-In relation to metallic contamination}

To assess the impact of metallic contamination with $\mathrm{Cu}$ and $\mathrm{Cd}$ on Zebrafish $A B C C 5$ gene, results of relative gene expression in Zebrafish different organs in the contaminated groups $\mathrm{F}$ and $\mathrm{G}$ were compared to the control groups $\mathrm{C}$ and $\mathrm{D}$. ABCC5 gene showed significant up-regulation by 2.4-times in brain samples of $\mathrm{F}$ group compared to the control group C. Although, digestive tract and muscles samples recorded non significant up-regulation with 2.5- and 1.4- times respectively, while gills showed down regulation by $1 / 3$ compared to $C$ group. 
Group C

(+fish -worms)

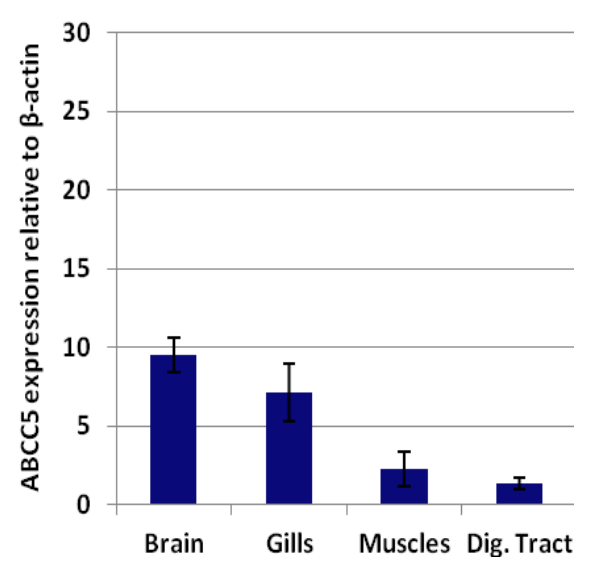

\section{Group F}

$(+\mathrm{Cu}+\mathrm{Cd}+$ fish -worms $)$

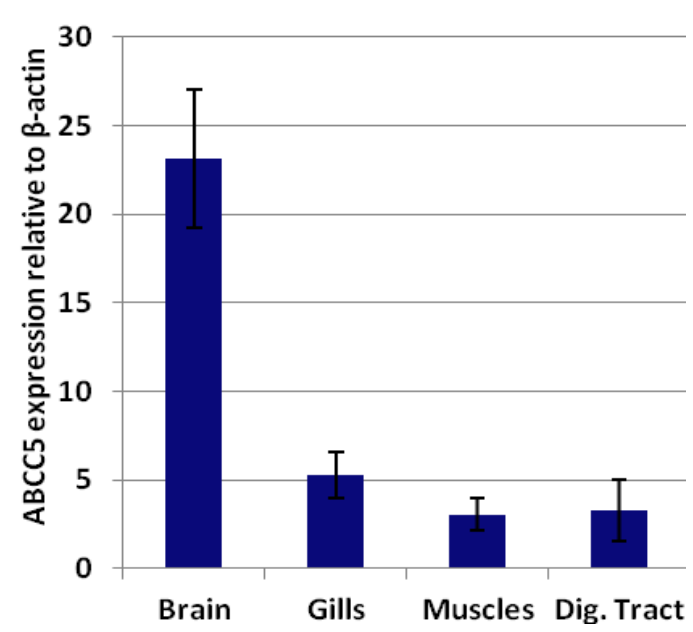

Group D

(+fish +worms)

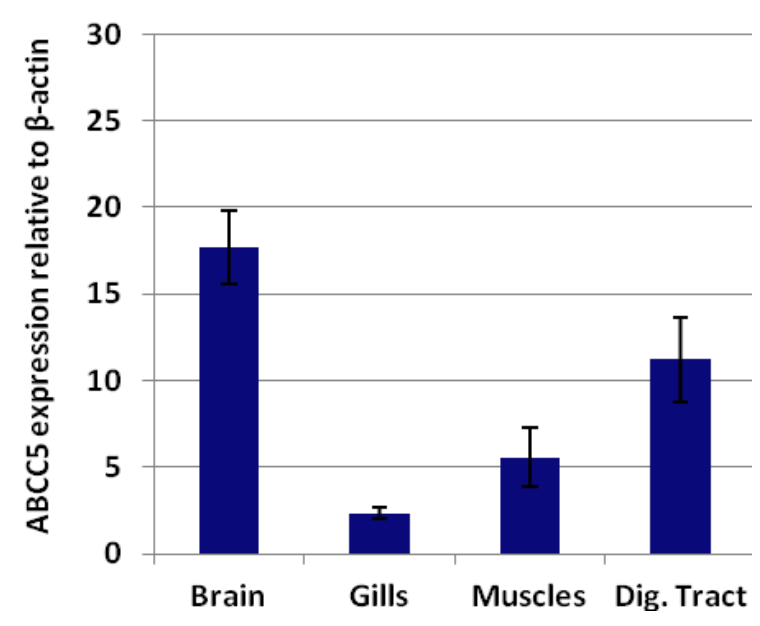

Group G

$(+\mathbf{C u}+\mathbf{C d}+$ fish +worms $)$

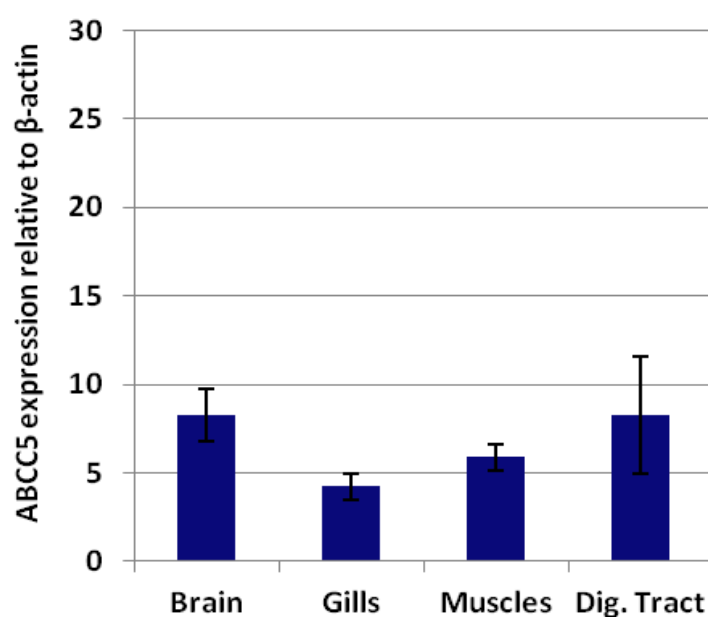

Fig. 1: Relative expression of $A B C C 5$ gene in Zebrafish Danio rerio

Zebrafish $\mathrm{ABCC} 5$ relative expression to $\beta$-actin in groups $C$ (Uncontaminated sediment + fish -worms), group D (Uncontaminated sediment + fish +worms), group F (Contaminated sediment + fish -worms) and group G (Contaminated sediment +fish +worms)

In $G$ group samples, $A B C C 5$ gene was significantly down-regulated by $1 / 2$ compared to D group samples. Moreover, gills and muscles samples recorded slight up-regulation in $A B C C 5$ gene expression by 1.8 and 1.1-times compared to D group samples, while digestive tract showed down-regulation by $1 / 3$ in the gene expression in $\mathrm{G}$ group samples compared to D group samples (table 2, figure 2).

Table 2: The differential gene expression of $A B C C 5$ gene in Zebrafish Danio rerio

\begin{tabular}{|c|c|c|c|c|c|c|}
\hline Tissue & D/C & F/C & G/C & F/D & G/D & G/F \\
\hline Brain & $1.9^{*}$ & $2.4^{*}$ & 0.9 & 1.3 & $0.5^{*}$ & $0.4^{*}$ \\
\hline Gills & 0.3 & 0.7 & 0.6 & 2.3 & 1.8 & 0.8 \\
\hline Muscles & 2.5 & 1.4 & 2.6 & 0.5 & 1.1 & 1.9 \\
\hline Digestive Tract & $8.6^{*}$ & 2.5 & $6.3^{*}$ & $0.3^{*}$ & 0.7 & 2.5 \\
\hline
\end{tabular}

$*$ Statistically Significant difference $(\mathrm{p}<0.05)$ 
$(\mathrm{F} / \mathrm{C})$

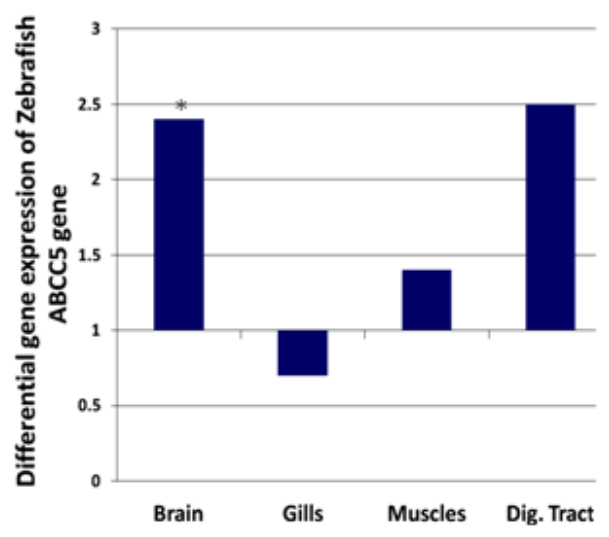

(G/D)

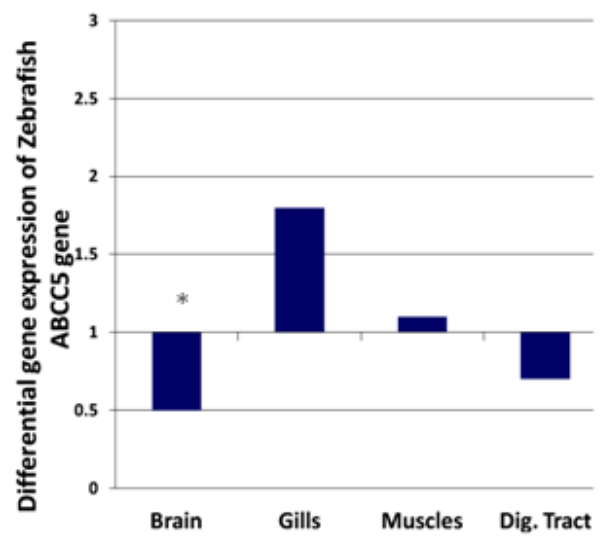

Fig. 2: Differential gene expression of Zebrafish ABCC5 gene in relation to metallic contamination. *Statistically Significant difference $(\mathrm{p}<0.05)$

\section{- In relation to Tubifex worms}

Results showed that Tubifex worms had a significant effect on the expression of Zebrafish ABCC5gene. Among the two control groups $\mathrm{C}$ and $\mathrm{D}$, digestive tract and brain samples of $\mathrm{D}$ group showed significant up-regulation in ABCC5 expression by 8.6- and 1.9-times respectively in comparison to the control group C. Whereas, in gills samples the $A B C C 5$ expression was down-regulated in $D$ group samples by $3 / 4$ compared to C group (Table 2, Figure 3).

In contaminated environment, the presence of Tubifex caused significant decrease by $1 / 3$ in the gene expression in brain samples of $G$ group compared to $F$ group samples, whereas $A B C C 5$ expression was up-regulated in $\mathrm{G}$ group samples by 2.5 and 1.9-times in digestive tract and muscles samples respectively.

$(\mathrm{D} / \mathrm{C})$

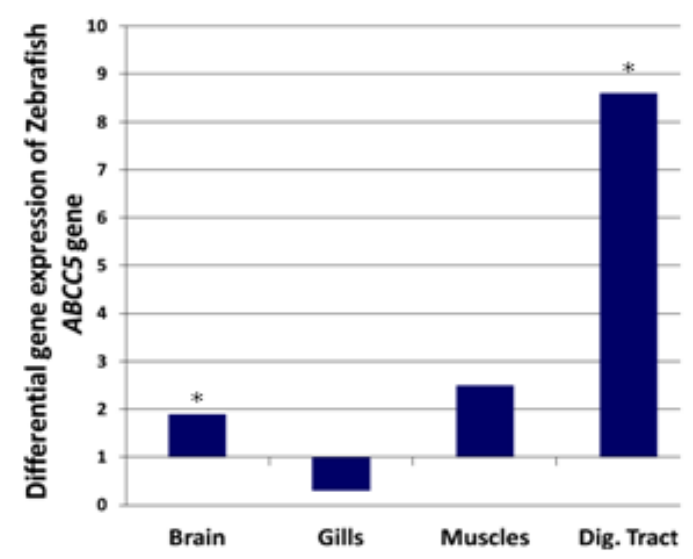

(G/F)

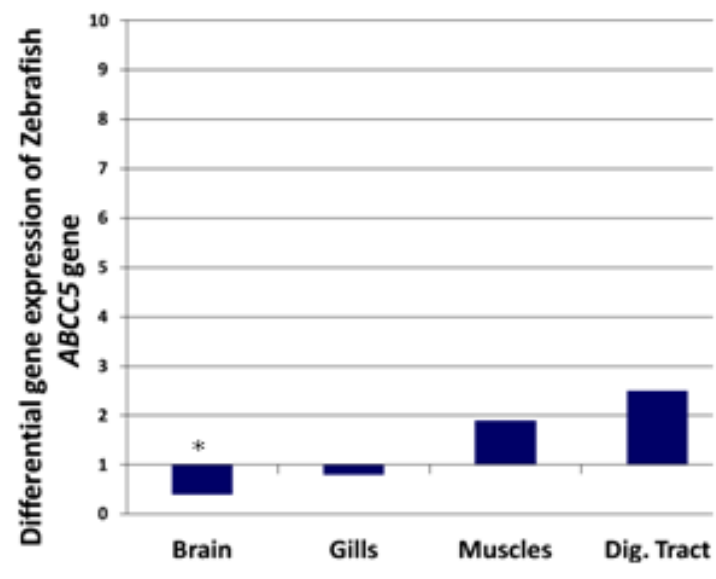

Fig. 3: Differential gene expression of Zebrafish ABCC5 gene in relation to Tubifex worms *Statistically Significant difference $(\mathrm{p}<0.05)$

\section{-In relation to both metallic contamination and the presence of Tubifex worms}

The effect of metallic contamination with $\mathrm{Cu}$ and $\mathrm{Cd}$ on Zebrafish ABCC5 gene expression in presence of Tubifex worms was presented in Table 2. The relative gene expression results for control group $\mathrm{C}$ (+fish -worms) were compared to the relative expression of $A B C C 5$ gene in the contaminated group $\mathrm{G}$ (+fish +worms). 
Significant increase in $A B C C 5$ expression in digestive tract samples in group $\mathrm{G}$ compared to $\mathrm{C}$ group by 6.3-times. A decrease in $A B C C 5$ expression was recorded in both gills and brain samples of $\mathrm{G}$ group (Figure 4).

$(\mathrm{G} / \mathrm{C})$

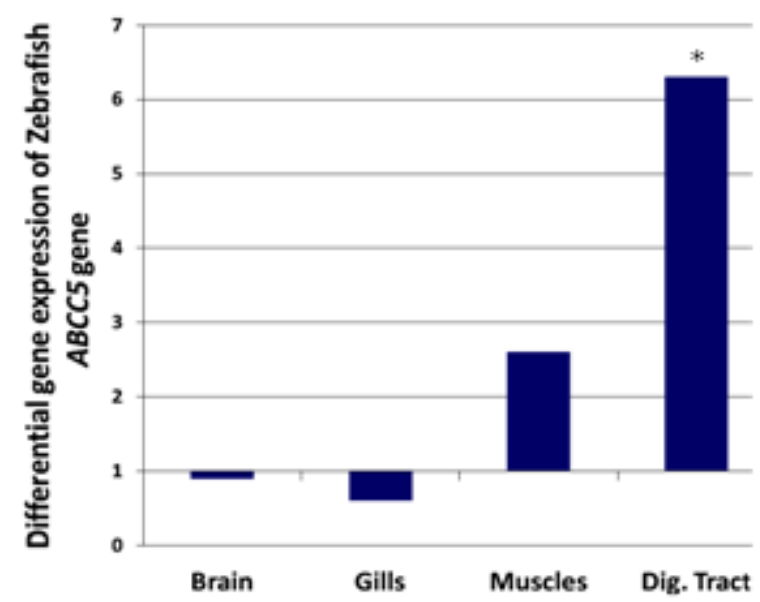

Fig. 4: Differential gene expression of Zebrafish ABCC5 in relation to both metallic contamination and the presence of Tubifex worms *Statistically Significant difference $(\mathrm{p}<0.05)$.

\section{DISCUSSION}

The role of $A B C C 5 / M R P 5$ gene in the defense mechanism of Zebrafish, Danio rerio against $\mathrm{Cu}$ and $\mathrm{Cd}$ contamination was investigated in this study. Also, the relative gene expression in presence and absence of a bioturbator organism such as Tubifex worms was studied.

$A B C C 5$ is an organic anion export pump which can pump toxins from the endothelial cells back into blood as a protective mechanism (Gomez-Pinedo et al., 2010), in addition to its role in intracellular signaling (Andric et al., 2006). ABCC5 is highly expressed in certain organs in adult Zebrafish, such as brain, eyes, ovaries and intestine, whereas low levels of gene expression can be recorded in gills, liver, heart and muscles (Long et al., 2011). Therefore, it is not surprising in this study to record the highest expression of $A B C C 5$ in brain samples in all the experimental groups. Moreover, significant up-regulation in zebrafish $A B C C 5$ expression in brain samples was recorded in the contaminated group $\mathrm{F}$ as a defense mechanism in Zebrafish brain tissue, since it participats in heavy metals detoxification or excretion outside the cells (Leslie et al., 2005).

In $\mathrm{F}$ group, this defense activity was very clear in brain and digestive tract samples, where $A B C C 5$ is mainly expressed. Significant up regulation by 2.4 - and 2.5 times was recorded in both organs respectively compared to control group C.

In previous study, Saglio et al. (1990) have recorded that some amino acids from Tubifex extract had a significant effect on the attraction and exploration behavior of Carp, Cyprinus carpio L. These stimulatory substances might be the cause of the high expression of $A B C C 5$ gene in brain, muscles and digestive tract samples of the control group D compared to C. It seems that Tubifex worms have a greater effect on Zebrafish than $\mathrm{Cu}$ and $\mathrm{Cd}$ contamination. 
Also, the relative expression of Zebrafish ABCC5 was compared in the contaminated group $\mathrm{G}$ to the control group D, where Tubifex worms were present in both groups, remarkable down-regulation in digestive tract and brain samples was recorded in group $\mathrm{G}$ compared to $\mathrm{C}$ group, this might be as a result of the reduction in Tubifex feeding activity in presence of contaminated sediment with $\mathrm{Cu}$ and $\mathrm{Cd}$ (Arrate et al., 2004). So, less movement in sediment -water interface cause less metal transfer, and less attraction and exploration behavior in fish, leading to less effect on zebrafish $A B C C 5$ in $\mathrm{G}$ group compared to $\mathrm{D}$ group. These results were more obvious in $\mathrm{G} / \mathrm{C}$ differential expression. When we compared Zebrafish ABCC5 expression in the control group $\mathrm{C}$ with the gene expression of Zebrafish $A B C C 5$ under the effect of both heavy metals contamination and Tubifex worms in group G, significant upregulation was recorded in digestive tract samples and in muscles as well in $G$ group compared to $\mathrm{C}$ group samples. However this up-regulation was less than the upregulation in gene expression due to the presence of Tubifex worms in control group D. Anthor hypothesis can explain the reduction of $A B C C 5$ expression in the contaminated group $\mathrm{G}$ in presence of Tubifex compared to the control group D. Due to the high ability of tubifex to bioacumulate high levels of metals such as $\mathrm{Cd}$ in its tissues (Ciutat \& Boudou, 2003, Arrate et al., 2004), it acts as a source of a very contaminated diet for Zebrafish causing serious levels of ROS and oxidative stress which might cause DNA damage, ATP depletion, inhibition in cells control on apoptotic death and finally make cells fall apart (Lee \& Shacter, 1999, Turpaev, 2002).

Fish like other aquatic organisms, normally uptake $\mathrm{Cu}$ and $\mathrm{Cd}$ from the surrounding environment and diet by gills and the digestive tract (Eiseler, 1998, McClelland et al., 2006).

Since the main source of contamination in this study was through contaminated sediment, low levels of $\mathrm{Cu}$ and $\mathrm{Cd}$ were transferred in water with the assistance of the bioturbator Tubifex worms.

Therefore, $A B C C 5$ in digestive tract and muscles samples showed more response to $\mathrm{Cu}$ and $\mathrm{Cd}$ exposure and Tubifex presence than in gill samples. Even though gills are the main site for metals uptake, they act as a short time storage organ (Lagadic et al., 1997, Amiard et al., 2006), transfer $\mathrm{Cu}$ and $\mathrm{Cd}$ to blood which by its turn transport them to other organs. These facts explain the results of the ABCC5 expression in gills samples, as it didn't show any significant response to any of the 4 groups.

\section{CONCLUSION}

The overall results recorded that $A B C C 5$ gene in brain and digestive tract tissues was more sensitive to contamination and Tubifex presence than in muscles and gills. While, gills didn't record any significant change related to the different treatments.

Furthermore, Tubifex has recorded higher effect on Zebrafish ABCC5 gene expression than the metallic contamination.

\section{ACKNOWLEDGMENT}

The authors would like to thank the Erasmus Mundus External Cooperation Window (EMECW)-FFEEBB program, and the University of Bordeaux1-France for the financial support to conduct this research in the laboratories of Arcachon Marine Station, Arcachon-France. 
Also we thank Dr. Aurélie Ciutat for her valuable assistance in tubifex treatment and Mr. Bruno Etcheverria for his technical assistance in animals' maintenance.

\section{REFERENCES}

Abdel-Gawad, S.T. and El-Sayed, A. (1998). An approach to identify the pollution field in Lake Manzala. Conference on coping with water scarcity 4.3., Hurghada, Egypt. 1-10.

Amiard, J.C.; Amiard-Triquet, C.; Barka, S.; Pellerin, J. and Rainbow, P.S. (2006). Metallothioneins in aquatic invertebrates: Their role in metal detoxification and their use as biomarkers. Aquat. Toxicol., 76(2):160-202.

Andric, S.A., Kostic, T.S. and Stojilkovic, S.S. (2006). Contribution of multidrug resistance protein MRP5 in control of cyclic guanosine 5'-monophosphate intracellular signaling in anterior pituitary cells. Endocrinol., 147(7): 3435-45.

Anschutz, P.; Ciutat, A.; Lecroart, P.; Gérino, M. and Boudou, A. (2012). Effects of Tubificid Worm Bioturbation on Freshwater Sediment Biogeochemistry. Aquat. Geochem., 1-23.

Arrate, J.A.; Rodriguez, P. and Martinez-Madrid, M. (2004). Tubifex tubifex chronic toxicity test using artificial sediment: methodological issues. Limnetica, 23 (1-2): 25-36.

Bagchi, D.; Joshi, S.S.; Bagchi, M.; Balmoori, J.; Benner, E.J.; Kuszynski, C.A. and Stohs, S. J. (2000). Cadmium- and chromium-induced oxidative stress, DNA damage, and apoptotic cell death in cultured human chronic myelogenous leukemic K562 cells, promyelocytic leukemic HL-60 cells, and normal human peripheral blood mononuclear cells. J. Biochem. Mol. Toxicol., 14(1): 33-41.

Bagdonas, E. and Vosylienė, M. Z. (2006). A study of toxicity and genotoxicity of copper, zinc and their mixture to rainbow trout (Oncorhynchus mykiss). Biologija , 1:8-13.

Barbosa, J.S.; Cabral, T.M.; Ferreira, D.N.; Agnez-Lima, L.F. and Batistuzzo de Medeiros, S. R. (2009). Genotoxicity assessment in aquatic environment impacted by the presence of heavy metals. Ecotoxicol. Environ. Saf., 73(3): 320-325.

Bertin, G. and Averbeck, D. (2006). Cadmium : cellular effects, modifications of biomolecules, modulation of DNA repair and genotoxic consequences (a review). Biochimie, 88: 1549-1559.

Blechinger, S.R.; Kusch, R. C.; Haugo, K.; Matz, C.; Chivers, D. P. and Krone, P. H. (2007). Brief embryonic cadmium exposure induces a stress response and cell death in the developing olfactory system followed by long-term olfactory deficits in juvenile zebrafish. Toxicol. Appl. Pharmacol., 224(1): 72-80.

Broughton, R.E.; Milam, J.E. and Roe, B.A. (2001). The complete sequence of the zebrafish (Danio rerio) mitochondrial genome and evolutionary patterns in vertebrate mitochondrial DNA. Genome Res., 11(11): 1958-67.

Cambier, S.; Gonzalez, P.; Durrieu, G. and Bourdineaud, J. P. (2010). Cadmiuminduced genotoxicity in zebrafish at environmentally relevant doses. Ecotoxicol. Environ. Saf., 73(3): 312-9.

Chan, P.K. and Cheng, S.H. (2003). Cadmium-induced ectopic apoptosis in zebrafish embryos. Arch. Toxicol., 77(2): 69-79. 
Ciutat, A. and Boudou, A. (2003). Bioturbation effects on cadmium and zinc transfers from a contaminated sediment and on metal bioavailability to benthic bivalves. Environ. Toxicol. Chem., 22(7): 1574-81.

Dean, M. and Anillo, T. (2005). Annual Review of Genomics and Human Genetics, 6: 123-142.

Eiseler, R. (1998). Copper Hazards to Fish, Wildlife, and Invertebrates: A Synoptic review. US Geological. Survey, Biological Resources Division, Biological Science Report USGS/BRD/BSR.

Fisher, J.B. (1982). Effects of macrobenthos on the chemical diagenesis of freshwater sediments. In: McCall PL, Tevesz MJS (eds) Animal-sediment relations. Plenum Press, New York, pp177-218.

Gabbianelli, R.; Lupidi, G.; Villarini, M. and Falcioni, G. (2003). DNA damage induced by copper on erythrocytes of gilthead sea bream Sparus aurata and mollusk Scapharca inaequivalvis. Arch. Environ. Contam. Toxicol., 45(3): 350-6.

Giaginis, C.; Gatzidou, E. and Theocharis, S. (2006). DNA repair systems as targets of cadmium toxicity. Toxicol. Appl. Pharmacol., 213: 282-290.

Gilbert, S. F. (2006). Developmental Biology ( $8^{\text {th }}$ edition), Sinauer Associates, Sunderland, MA, USA. pp. 325-335.

Gillis, P.L.; Dixon, D.G.; Borgmann, U. and Reynoldson, T.B. (2004). Uptake and depuration of cadmium, nickel, and lead in laboratory-exposed Tubifex tubifex and corresponding changes in the concentration of a metallothionein-like protein. Environ. Toxicol. Chem., 23(1): 76-85.

Glanze, W.D. (1996). Mosby Medical Encyclopedia, Revised Edition 1996. St. Louis MO: C.V. Mosby.

Gomez-Pinedo, U.; Rodrigo, R.; Cauli, O.; Herraiz, S.; Garcia-Verdugo, J.M.; Pellicer, B.; Pellicer, A. and Felipo, V. (2010). cGMP modulates stem cells differentiation to neurons in brain in vivo. Neurosci., 165(4): 1275-83.

Hill, A.J.; Teraoka, H.; Heideman, W. and Peterson, R.E. (2005). Zebrafish as a model vertebrate for investigating chemical toxicity. Toxicol. Sci., 86: 6-19.

IARC. (1993). Cadmium and cadmium compounds. In: Beryllium, Cadmium, Mercury and Exposure in the Glass Manufacturing Industry. IARC Monographs on the Evaluation of Carcinogenic Risks to Humans, Lyon: International Agency for Research on Cancer, 58: 119-237.

Jha, A.N. (2008). Ecotoxicological applications and significance of the comet assay. Mutagen., 23 (3): 207-21.

Jin, Y.; Wang, W.; Xu, C.; Fu, Z. and Liu, W. (2008). Induction of hepatic estrogenresponsive gene transcription by permethrin enantiomers in male adult zebrafish. Aquat. Toxicol., 88(2):146-52.

Jones, P.M. and George, A.M. (2004). The ABC transporter structure and mechanism: perspectives on recent research. Cell. Mol. Life Sci., 61(6): 682-699.

Joseph, P. (2009). Mechanisms of cadmium carcinogenesis. Toxicol. Appl. Pharmacol., 238: 272-279.

Lagadic, L.; Caquet, T.; Amiard, J.C. and Ramade, F. (1997). Biomarqueurs en écotoxicologie. Aspects fondamentaux. Eds. Collection Écologie, Paris, Masson, $419 \mathrm{pp}$.

Lee, Y. j. and Shacter, E. (1999). Oxidative Stress Inhibits Apoptosis in Human Lymphoma Cells. J. Biol. Chem., 274(28): 19792-19798. 
Leslie, E. M.; Deeley, R. G. and Cole, S. P. (2005). Multidrug resistance proteins: role of P-glycoprotein, MRP1, MRP2, and BCRP (ABCG2) in tissue defense. Toxicol. Appl. Pharmacol., 204(3): 216-37.

Long, Y.; Li, Q.; Li, J. and Cui, Z. (2011). Molecular analysis, developmental function and heavy metal-induced expression of ABCC5 in zebrafish. Comparative Biochemistry and Physiology Part B: Biochem. Mol. Biol., 158(1): 46-55.

Matsumoto, S.T.; Mantovani, M.R.S.R.; Malaguttii, M.I.A.; Dias, A.L.C.; Fonseca, I.S.C. and Marin-Morales, M.A. (2006). Genotoxicity and mutagenicity of water contaminated with tannery effluents, as evaluated by the micronucleus test and comet assay using the fish Oreochromis niloticus and chromosome aberrations in onion root-tips. Gen. Mol. Biol., 29: 148-158.

McClelland, G.B.; Craig, P.M.; Dhekney, K. and Dipardo, S. (2006). Temperatureand exercise-induced gene expression and metabolic enzyme changes in skeletal muscle of adult zebrafish (Danio rerio). J. Physiol., 577(2): 739-51.

Nehls, S. and Segner, H. (2001). Detection of DNA damage in two cell lines from rainbow trout, RTG-2 and RTL-W1, using the comet assay. Environ. Toxicol., 16(4): 321-9.

Orieux, N.; Cambier, S.; Gonzalez, P.; Morin, B.; Adam, C.; Garnier-Laplace, J. and Bourdineaud, J.P. (2011). Genotoxic damages in zebrafish submitted to a polymetallic gradient displayed by the Lot River (France). Ecotoxicol. Environ. Saf., 74(4): 974-83.

Pomati, F.; Orlandi, C.; Clerici, M.; Luciani, F. and Zuccato, E. (2008). Effects and interactions in an environmentally relevant mixture of pharmaceuticals. Toxicol. Sci., 102(1): 129-37.

Ponte-Sucre, A. (2009). ABC Transporters in Microorganisms. Caister Academic Press.

Rank, J.; Jensen, K. and Jespersen, P.H. (2005). Monitoring DNA damage in indigenous blue mussels (Mytilus edulis) sampled from coastal sites in Denmark. Mut. Res., 585(1-2): 33-42.

Ricard, A.C.; Daniel, C.; Anderson, P. and Hontela, A. (1998). Effects of subchronic exposure to cadmium chloride on endocrine and metabolic functions in rainbow trout Oncorhynchus mykiss. Arch. Environ. Contam. Toxicol., 34(4): 377-81.

Rivera-Mancia, S.; Perez-Neri, I.; Rios, C.; Tristan-Lopez, L.; Rivera-Espinosa, L. And Montes, S. (2010). The transition metals copper and iron in neurodegenerative diseases. Chem-Biol. Inter., 186(2), 184-99.

Rocco, L., Izzo, A., Zito, G., Peluso, C. \& Stingo, V. (2011). Genotoxicity in Zebrafish (Danio rerio) Exposed to two Pharmacological Products from an Impacted Italian River. J. Environ. Anal. Toxicol., 1(2): 103.

Saeed, M.S and Shaker, I. M. (2008). Assessment of heavy metals Pollution in water and sediment and their effect on organisms Niloyics in the Northern Delta Lakes, Egypt. $8^{\text {th }}$ International Symposium on of sediment and fish from ElMax Bay, Alexandria, Tilapia in Aquaculture.

Saglio, P.; Fauconneau, B. and Blanc, J. M. (1990). Orientation of carp, Cyprinm carpio L., to free amino acids from Tubifex extract in an olfactometer. J. Fish Biol., 37(6): 887-898.

Schneider, E. and Hunke, S. (1998). ATP-binding-cassette (ABC) transport systems: functional and structural aspects of the ATP-hydrolyzing subunits/domains. FEMS Microbiol. Rev., 22(1):1-20. 
Scholz, S.; Fischer, S.; Gündel, U.; Küster, E.; Luckenbach, T. and Voelker, D. (2008). The zebrafish embryo model in environmental risk assessmentapplications beyond acute toxicity testing. Environ. Sci. Pollut. Res., 15(5): 394-404.

Spitsbergen, J.M. and Kent, M.L. (2003). The state of the art of the zebrafish model for toxicology and toxicologic pathology research advantages and current limitations. Toxicol. Pathol., 31(Suppl): 62-87.

Teles, M.; Pacheco, M. and Santos, M.A. (2005). Physiological and genetic responses of European eel (Anguilla anguilla L.) to short-term chromium or copper exposure-Influence of pre-exposure to a PAH-like compound. Environ. Toxicol., 20(1): 92-99.

Teraoka, H.; Dong, W. and Hiraga, T. (2003). Zebrafish as a novel experimental model for developmental toxicology. Congen. Anom. (Kyoto), 43(2), 123-32.

Turpaev, K.T. (2002). Reactive oxygen species and regulation of gene expression. Biochem. (Mosc), 67(3): 281-92.

Van der Geest, H.G. and Leon Paumen, M. (2008). Dynamics of metal availability and toxicity in historically polluted floodplain sediments. Sci. Total Environ., 406(3): 419-25.

Weaver, D.A.; Crawford, E.L.; Warner, K.A.; Elkhairi, F.; Khuder, S.A. and Willey, J.C. (2005). ABCC5, ERCC2, XPA and XRCC1 transcript abundance levels correlate with cisplatin chemoresistance in non-small cell lung cancer cell lines. Mol. Cancer, 4(1): 18.

Zendt, J.S, and Bergersen, E.P. (2000). Distribution and abundance of the aquatic oligochaete host Tubifex tubifex for the salmonid whirling disease parasite Myxobolus cerebralis in the upper Colorado River basin. N. Am. J. Fish. Manag., 20(2): 502-512.

\section{ARABIC SUMMARY}

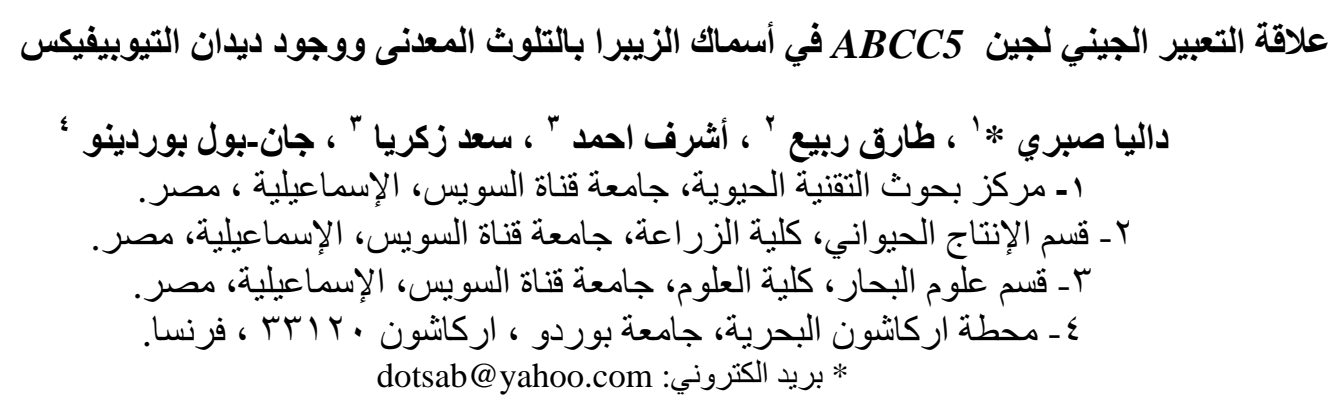

يهذف هذا البحث إلى دراسة تأثير الرواسب الملوثة بالنحاس و الكادميوم على التعبير الجيني لجين ABCC5

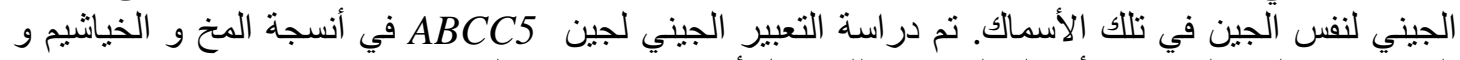

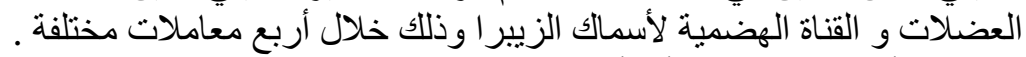

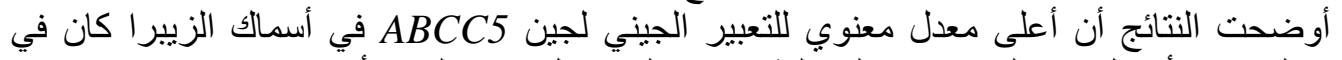

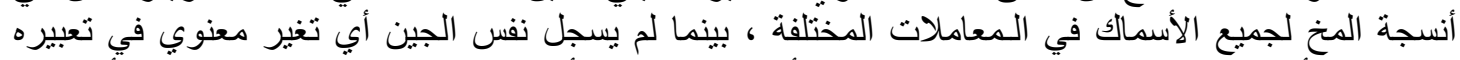

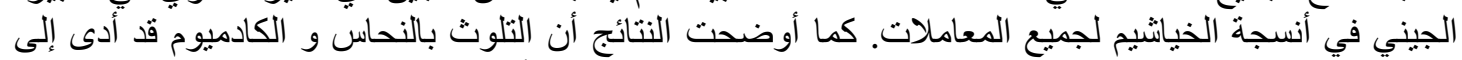

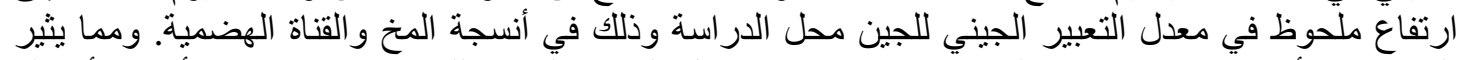

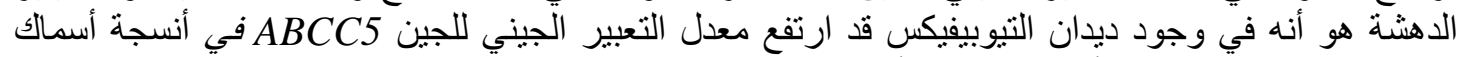

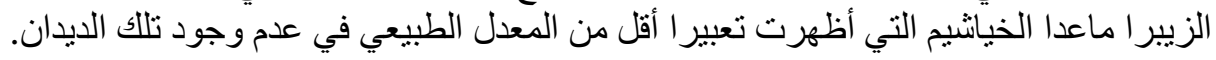

